\title{
The performance of split and integrated types air-source heat pump water heaters in South Africa
}

\author{
Stephen Loh Tangwe ${ }^{1,2 *}$ Michael Simon ${ }^{1}$, Russel Mhundwa ${ }^{1}$ \\ a Fort Hare Institute of Technology, University of Fort Hare, Private Bag X1314, Alice5700, South Africa \\ b Faculty of Engineering and Advanced Manufacturing, University of Sunerland, Tyne \& Wear, SR1 3SD, \\ United Kingdom
}

\begin{abstract}
Renewable energy technologies that can provide optimum and cost-effective energy savings to mitigate global warming, energy crisis and to achieve energy efficiency continue to be of paramount importance. The present study focused on identifying critical parameters such as the volume of hot water drawn off; ambient temperature; relative humidity; refrigerant temperatures at the inlet and outlet of the compressor and condenser; and deterministic quantities such as time used, power consumption and coefficient of performance (COP) as indicators to benchmark the performance of both the split and integrated types of air-source heat pump (ASHP) water heaters. The basis for analysis was on two predominant scenarios: first-hour heating rating and the heating cycle due to controlled volume of hot water drawn-off wherein both the integrated and split types ASHP water heaters experienced vapour compression refrigeration cycles. A data acquisition system was constructed and implemented to monitor the performance of both sys-
\end{abstract}

tems. The results obtained during summer season showed that, under the scenario of $150 \mathrm{~L}$ hot water withdrawal, the average COP of the systems was 3.18 and 2.85 for the split and integrated types respectively. The average power consumed was 1.29 (split type) and $0.85 \mathrm{~kW}$ (integrated type). The times of operation were 84 minutes (split type) and 138 minutes (integrated type).

Keywords: coefficient of performance; vapour compression refrigeration cycle; renewable energy technologies

Journal of Energy in Southern Africa 29(2): 12-20

DOI: http://dx.doi.org/10.17159/2413-3051/2018/v29i2a4358

Published by the Energy Research Centre, University of Cape Town ISSN: 2413-3051 http://journals.assaf.org.za/jesa

Sponsored by the Department of Science and Technology

\footnotetext{
* Corresponding author: Tel: +27 78307 6922;

email: STangwe@ufh.ac.za
} 


\section{Introduction}

Residential hot water heating offers an opportunity for energy savings, and the heat pump water heater provides a promising technology. The vapour compression refrigeration cycles is a process whereby refrigerant in the closed circuit loop of the heat pump undergoes phase change between the evaporator and condenser unit in a bid to transfer useful thermal energy. It can generate sanitary hot water by harnessing the aero-thermal energy during the vapour compression refrigeration cycle (VCRC). In South Africa, more than $90 \%$ of electrical energy is generated from coal and is solely supplied by Eskom ( Van Eeden et al., 2016). The global warming potential caused by greenhouse gases, primarily carbon dioxide, is $510 \mathrm{Mt}$, of which $45 \%$ emanates from coal-fired power plants (Bryson, 2011; Van Eeden el al., 2016).

Producing hot water accounts for up to $50 \%$ of domestic electricity use (Meyer and Tshimankinda, 1998; Tangwe et al., 2015). The energy factor for a geyser is the ratio of useful stored thermal energy in the cylinder to the input electrical energy consumed. The conventional heater (electric geyser) predominates, with an average energy factor of 0.92 (Huang and Lin, 1997; Tangwe et al., 2014). A possible alternative is the more energy-efficient air source heat pump (ASHP) water heater (Morrison et al., 2004), which can provide energy savings in the range of $50-70 \%$, as it has a coefficient of performance (COP) that ranges from 2 to 4 (De Swardt and Meyer, 2001; Bodzin, 1997). The ASHP operates on the principle of VCRC and is a reverse air conditioner process (Marrison et al., 2004). The thermo-physical properties of the refrigerant also contributes to the performance of the ASHP unit. The refrigerants used as the primary fluid for both the split and integrated types of ASHP water heaters were R417A and R407C of the zeotropic type with almost equal critical temperatures and critical pressures. The heat transfer coefficient of R417A is better than for R407C (Aprea et al., 2008).

In a bid to reduce demand on the national grid during peak hours, Eskom targeted rolling out 65580 ASHP units up to March 2013 under a residential rebate scheme ( Zhang et al., 2012). This strategy was expected to reduce annual demand by 54 MW, with savings of about 80.86 GWh during morning and evening peak hours. Having real-time data on the COP of ASHP water heaters was necessary, as any reliable mathematical model and simulation application to compute savings depended on the accuracy of data employed in the algorithm.

There are two categories of ASHP water heaters: the integrated and the split types (Marrison et al., 2004). The integrated type comprises an ASHP unit and a storage tank as a compact system, with the tank below the heat pump unit. It is commonly configured in two forms: one with an auxiliary backup heating element and the other without any backup element. Similarly, the split type also is in two groups: the single passed or 'once passed' type, and the recirculation system type. It can also operate with or without a backup element. The investigation reported on here was conducted with a split type ASHP water heater without an auxiliary backup element, and an integrated type ASHP water heater with a backup element. Both had a capacity of 150 L. The primary aim was to use identified predictors such as ambient temperature, relative humidity, and the refrigerant temperatures at the inlet and outlet of the compressors and condensers, to analytically determine which of the two systems demonstrated a better performance in terms of COP.

The objectives of the study were to:

- determine the COPs of both split and integrated types of ASHP water heaters under different heating cycle scenarios, with controlled volumes of hot water drawn off;

- evaluate the performance of the two types, based on the average COP, power and energy consumption under the different heating cycle scenarios; and

- ascertain the performance of the two types of heat pump water heaters by the predictors (power consumed, power factor, ambient temperature, relative humidity, inline cold water temperature, refrigerant temperatures at the inlet and outlet of the compressor and condenser) during the VCRC.

\section{Material and methodology 2.1 Material}

Table 1 lists the experimental material: hot water heating technologies, sensors and data loggers. Figure 1 shows the installation of the split and integrated ASHP water heaters used for investigation. A data logger was incorporated to monitor the thermodynamic temperature profiles of the refrigerant during the VCRC, the volume of water heated, and the electrical energy consumption of the systems. A full description of the sensors and DAS has been published elsewhere (Tangwe et al., 2016).

\subsection{Methods}

The hot water in each of the storage tanks was set at $55{ }^{\circ} \mathrm{C}$ through the control button of the ASHP water heater. Temperature sensors were installed on the inlet and outlet pipes attached to the split type ASHP, to measured the temperature of the water flowing into and out of the unit. Temperature sensors were also installed on the four critical locations (compressor suction and discharge ends, and the inlet and outlet ends of the condenser) that constitute the closed loop circuit designed for the VCRC intended to take place on each of the ASHP units 
Table 1: Experimental material.

\begin{tabular}{ll}
\hline Devices and sensors & Purpose \\
\hline $\begin{array}{l}1.2 \mathrm{~kW} \text { SIRAC air-source heat pump } \\
\text { (split type unit with refrigerant (R417A)) }\end{array}$ & To retrofit a 150 L geyser tank with its $3 \mathrm{~kW}$ electric element disabled \\
\hline $\begin{array}{l}\text { 0.9 } \mathrm{kW} \text { AIRCO ASHP (integrated type } \\
\text { water heater with refrigerant (R407C)) }\end{array}$ & $\begin{array}{l}\text { Acted as an integrated type ASHP water heater with a compact 150 L } \\
\text { storage tank }\end{array}$ \\
\hline $\begin{array}{l}\text { A 150 L high-pressure geyser (hot water } \\
\text { cylinder) }\end{array}$ & $\begin{array}{l}\text { Served as a hot water storage tank for the split type ASHP unit as its } \\
\text { electric element is disabled }\end{array}$ \\
\hline Two quality track power meters & $\begin{array}{l}\text { Measured the electrical power consumption of both types of ASHP } \\
\text { water heaters }\end{array}$ \\
\hline Twelve temperature sensors & $\begin{array}{l}\text { Measured the temperatures at different locations of the two types of } \\
\text { ASHP water heaters }\end{array}$ \\
\hline $\begin{array}{l}\text { Ambient temperature and relative } \\
\text { humidity sensor }\end{array}$ & $\begin{array}{l}\text { Measured the ambient temperature and relative humidity } \\
\text { A flow meter }\end{array}$ \\
\hline 100 L calibrated water drum & $\begin{array}{l}\text { Measured the water flow rate into the inlet of the split type ASHP unit } \\
\text { connected to each of the ASHP water heaters }\end{array}$ \\
\hline
\end{tabular}

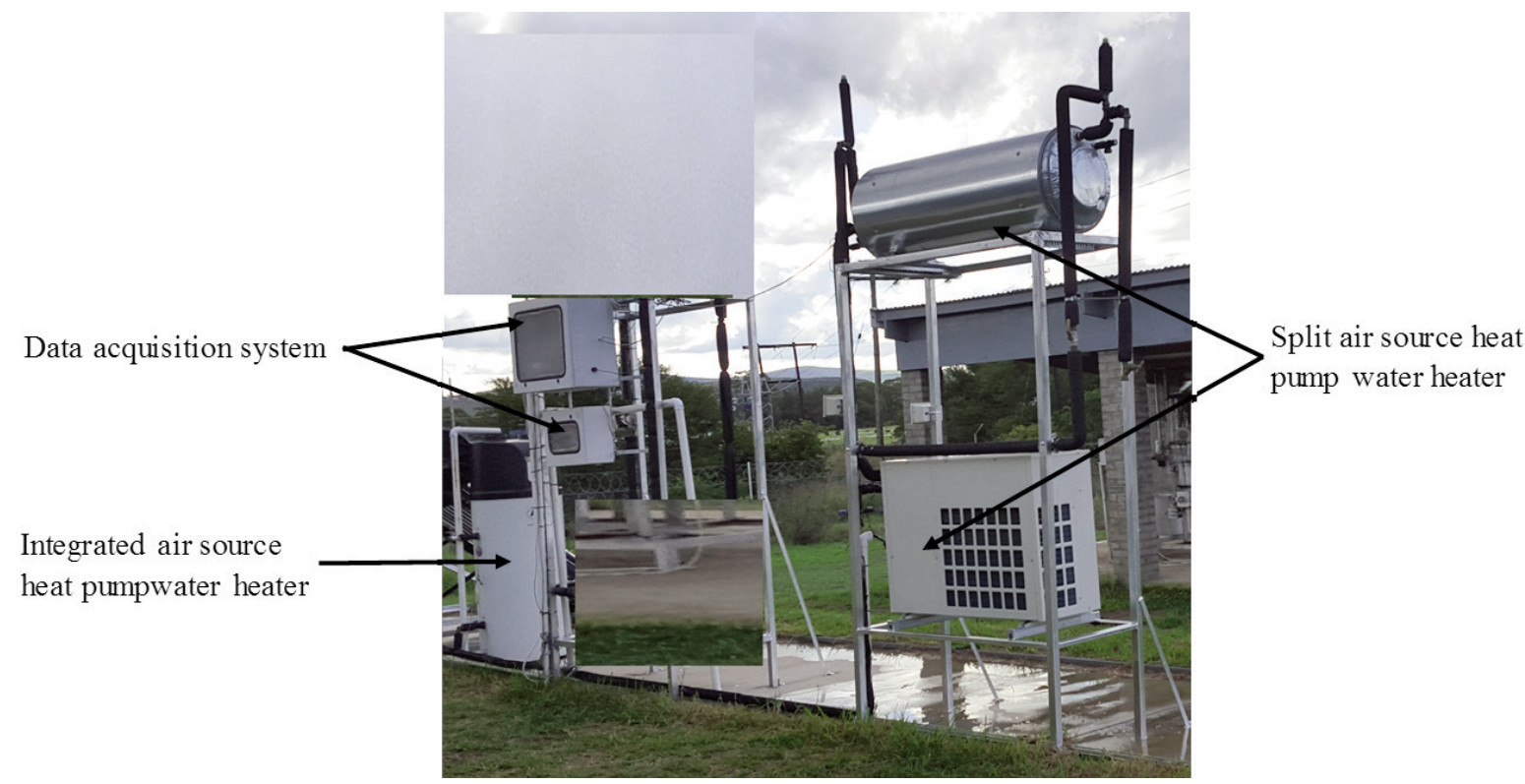

Figure 1: Experimental set up for the investigation.

during operation. These sensors measured temperatures of the refrigerant at the inlet and outlet of the compressor and condenser in each of the ASHP units. An in-line cold water temperature sensor was installed on the pipeline feeding mains cold water into the storage tanks of both types of water heater. A T-Minol 130 flow meter was connected to the inlet pipe of the split type unit, measuring the volume of water heated by it. These flow measurements were recorded by the data logger via a connecting cable integrated with a S-UCD electronic input pulse adapter and further stored in counts, with one count representing $3.7854 \mathrm{~L}$. The quality power track meters featured inbuilt data logging capability and were installed to measure the active power in kilowatts $(\mathrm{kW})$, the reactive power in reactive kilovolt-amperes (kVAR) and the apparent power in kilovolt-amperes (kVA). These three measurements and the power factor were stored into the inbuilt data logger of the power meter. The ambient temperature and relative humidity sensors were protected by a solar radiation shield. The refrigerant temperature measurements, the water temperature, the volume of water heated, the ambient temperature and the relative humidity data, were stored in a U30-NRC Hobo data logger. All the temperature sensors and the ambient temperature and relative humidity sensor were integrated with a S-UCC electronic input pulse adapter attached to the connecting cables. These electronic input pulse adapters converted the analogue sensing signals to digital in order to circumvent the effect of noise interference. The data logger was configured to log every oneminute interval for the duration of the experiment. The experimental data was collected and analysed for a full year, from October 2015 to September 2016, for controlled volumes of hot water withdrawal (150, 50 and $100 \mathrm{~L})$, and for three times: 
morning, afternoon and evening. According to (Ye and Zhang, 2012), these periods coincided with Eskom's morning and evening peak periods of electrical energy and hot water consumption. The afternoon draw off does not resulted to any peak but included to capture the average daily typical residential hot water demand profile.

The procedure involved four activities:

(a) monitoring the performance of the two systems under $50 \mathrm{~L}$ hot water withdrawal, in three operation sessions (morning, afternoon and evening);

(b) monitoring the performance of the two systems under $100 \mathrm{~L}$ hot water withdrawal, in the three sessions;

(c) monitoring the performance of the two systems under first-hour heating rating (150 L drawn off) for the three sessions; and

(d) a comparative detail analysis of all the heating cycle scenarios of the two systems for both summer and winter.

\section{Theory and calculations}

The useful output thermal energy gained by the stored water is given by Equation 1.

$$
Q=m c \delta T
$$

where $\mathrm{Q}=$ useful thermal energy gained in $\mathrm{kWh}, \mathrm{m}$ $=$ mass of water heated in $\mathrm{kg}, \mathrm{c}=$ specific heat capacity of water in $\mathrm{kJ} / \mathrm{kg}$ and $\delta T=$ temperature change in ${ }^{\circ} \mathrm{C}$.

The input electrical energy consumed by the ASHP water heater is given by Equation 2 .

$$
\mathrm{E}=\mathrm{Pt}
$$

where $\mathrm{P}=$ electrical power consumed in $\mathrm{kW}, \mathrm{t}=$ time taken for the VCRC in hours and $\mathrm{E}=$ electrical energy consumption in $\mathrm{kWh}$.

The COP of the ASHP water heater is also given by Equation 3 .

$$
\mathrm{COP}=\frac{\mathrm{Q}}{\mathrm{E}}
$$

where $\mathrm{COP}=$ coefficient of performance of the ASHP water heater.

\section{Results and discussion}

The analysis used performance data of the two types of ASHP water heaters for the full year from October 2015 to September 2016.

\subsection{Summer performance of the two systems when $50 \mathrm{~L}$ of hot water is drawn off}

The split and integrated types ASHP water heater systems were switched off and $50 \mathrm{~L}$ hot water was drawn from each tank and replaced with cold water from the in-line pipe feeding both tanks via the inlet pipe of each tank. After the withdrawal, the systems were switched on, at a common circuit breaker. The analysis was based on the morning (from 08:00), afternoon (from 13:00) and evening (from 18:00) data for a week in March 2016. The performance of the two systems on each of the operation times was analytically evaluated, with all the relevant predictors examined: power consumed, power factor, relative humidity, ambient temperature, inline cold water temperature, and refrigerant temperatures at the inlet and outlet of the compressor and condenser, as shown in Table 2.

The average power consumed and the duration to complete the VCRC by both split and integrated type heaters in the morning drawn-off scenario was 1.30 and $0.86 \mathrm{~kW}$, with the VCRC durations of 40 and 70 minutes, respectively. Average power consumed and time taken was $1.5 \mathrm{~kW}$ and 45 minutes for the split type system, while for the integrated type system it was $0.9 \mathrm{~kW}$ and 65 minutes during the afternoon drawn-off scenario. Table 2 shows the evening drawn-off average power consumed, and the duration for the VCRC, for the split type system as $1.35 \mathrm{~kW}$ and 40 minutes, as opposed to $0.87 \mathrm{~kW}$ and 70 minutes for the integrated type system. The higher input power consumption of the split system aided the completion of the VCRC in a shorter time, when compared with the integrated type. The average power consumption for both systems was highest during the afternoon drawn-off scenario because of the corresponding increase in ambient temperature and inline cold water temperature experienced during this period. Also, the input power during VCRC is strongly ambient temperature dependant.

Table 2 shows that both systems had an excellent power factor of 0.98 in all three periods. There were negligible variations in the relative humidity, ambient temperature and initial cold water temperature during the VCRC that occurred in the two systems in the morning period, and their averages were respectively $72 \%, 19.4{ }^{\circ} \mathrm{C}$ and $18.7^{\circ} \mathrm{C}$. The averages of the relative humidity, ambient temperature and initial cold water temperature during the VCRC that occurred in the two systems in the afternoon period were respectively $36 \%, 29.5{ }^{\circ} \mathrm{C}$ and $26.5{ }^{\circ} \mathrm{C}$. The respective averages of the relative humidity, ambient temperature and initial cold water temperature during the VCRC encounter by the two systems in the evening period were $86 \%$, $18.6^{\circ} \mathrm{C}$ and $19.5^{\circ} \mathrm{C}$. The significantly increased in the ambient temperature and also the inline cold water temperature in the afternoon period during the VCRC due to the $50 \mathrm{~L}$ drawn-off were responsible for the increase in average power consumption for the both systems.

Although the average refrigerant temperature at the compressor inlet of the integrated system was lower than that of the split system in the morning 
Table 2: Averages of the critical parameters when $50 \mathrm{~L}$ of hot water is drawn off.

\begin{tabular}{|c|c|c|c|c|c|c|}
\hline \multirow[t]{2}{*}{ Parameter } & \multicolumn{2}{|c|}{ Morning period } & \multicolumn{2}{|c|}{ Afternoon period } & \multicolumn{2}{|c|}{ Evening period } \\
\hline & SIRAC & AIRCO & SIRAC & AIRCO & SIRAC & AIRCO \\
\hline$\overline{\mathrm{P}(\mathrm{kW})}$ & 1.30 & 0.86 & 1.50 & 0.90 & 1.35 & 0.87 \\
\hline $\mathrm{PF}$ & 0.98 & 0.98 & 0.98 & 0.98 & 0.98 & 0.98 \\
\hline $\mathrm{RH}(\%)$ & 72.00 & 72.00 & 36.00 & 36.00 & 86.00 & 86.00 \\
\hline $\mathrm{AT}\left({ }^{\circ} \mathrm{C}\right)$ & 19.40 & 19.40 & 29.50 & 29.50 & 18.60 & 18.60 \\
\hline Ticw $\left({ }^{\circ} \mathrm{C}\right)$ & 18.70 & 18.70 & 26.50 & 26.50 & 19.50 & 19.50 \\
\hline Tcomi $\left({ }^{\circ} \mathrm{C}\right)$ & 25.20 & 10.70 & 22.50 & 12.30 & 22.50 & 12.30 \\
\hline Tcomo $\left({ }^{\circ} \mathrm{C}\right)$ & 73.00 & 51.60 & 65.60 & 52.80 & 65.60 & 52.80 \\
\hline Tconi $\left({ }^{\circ} \mathrm{C}\right)$ & 70.00 & 50.00 & 64.00 & 51.00 & 64.00 & 51.00 \\
\hline Tcono $\left({ }^{\circ} \mathrm{C}\right)$ & 39.10 & 47.10 & 29.00 & 45.00 & 34.00 & 47.10 \\
\hline
\end{tabular}

scenario, $10.7^{\circ} \mathrm{C}$ and $25.2^{\circ} \mathrm{C}$, more thermal energy was gained by the refrigerant as it entered the suction end and exited the discharge end of the compressor in the split type, contrary to what happened in the integrated type. Moreover, the amount of the thermal energy gained was a function of the change in the refrigerant temperature at the inlet and outlet of the compressor and was $47.8^{\circ} \mathrm{C}$ and $40.9{ }^{\circ} \mathrm{C}$ for the split and integrated types respectively. The average temperature of the refrigerant at the inlet of the compressor in the integrated type system was lower than that of the split type in the afternoon scenario, with respective temperatures of $12.3{ }^{\circ} \mathrm{C}$ and 22.5 ${ }^{\circ} \mathrm{C}$. The amount of the thermal energy gained was proportional to the change in the temperature of the refrigerant at the inlet and outlet of the compressors, at $43.1{ }^{\circ} \mathrm{C}$ and $40.5{ }^{\circ} \mathrm{C}$ for the split and integrated type ASPH water heaters respectively. The results showed that the average temperature of the refrigerant at the inlet of the compressor in the integrated type system was lower than that of the split type in the evening scenario, at $12.3{ }^{\circ} \mathrm{C}$ and 22.5 ${ }^{\circ} \mathrm{C}$. The amount of the thermal energy gained was proportional to the change in the temperature of the refrigerant at the inlet and outlet of the compressors and was $43.1{ }^{\circ} \mathrm{C}$ and $40.5^{\circ} \mathrm{C}$ for the split and integrated types respectively. In all three scenarios, the refrigerant temperature at the inlet of the compressor was higher in the split type than in the integrated type, but the difference in the outlet and inlet temperature of the compressors was higher in the split type.

The amount of useful thermal energy gained by the hot water was a function of change in refrigerant temperature between the inlet and outlet of the condensers. The morning period average showed a difference in the change of the refrigerant temperature at the inlet and outlet of the condensers in the split type system $\left(30.9^{\circ} \mathrm{C}\right)$, and the integrated type system $\left(2.9^{\circ} \mathrm{C}\right)$ of $28.0^{\circ} \mathrm{C}$. The refrigerants used in the two systems (R407C and R417A) were zeotropic, so the temperature gliding occurred at the condensers as well as at the evaporators during the VCRC. The afternoon drawing-off shows a difference of 29.0 ${ }^{\circ} \mathrm{C}$ in the refrigerant temperature at the inlet and outlet of the condensers in the split and integrated systems (from $35.0^{\circ} \mathrm{C}$ to $6.0^{\circ} \mathrm{C}$ ). The evening averages show a difference of $26.1{ }^{\circ} \mathrm{C}$ at the inlet and outlet of the condensers in the split and integrated systems (from $30.0^{\circ} \mathrm{C}$ to $3.9^{\circ} \mathrm{C}$ ).

Analysis, supported by theory, thus showed that the split type had a better performance than the integrated type in all the scenarios, with a higher refrigerant temperature difference between the condenser inlet and outlet.

\subsection{Summer performance of the two systems when $100 \mathrm{~L}$ of hot water is drawn off}

The procedure described in Section 4.1 was repeated, but this time with $100 \mathrm{~L}$ of hot water drawn off. Table 3 shows the averages of the nine parameters examined.

The morning average power consumption of the split type system was $1.20 \mathrm{~kW}$ as opposed to 0.86 $\mathrm{kW}$ for the integrated type, with VCRC durations of 70 and 110 minutes respectively. The afternoon drawing-off showed an average power consumption for the split type system of 1.30 and $0.89 \mathrm{~kW}$ for the integrated type system, with VCRC durations of 60 and 100 minutes respectively. The evening drawing-off showed an average power consumption for the split type system of 1.29 and 0.89 $\mathrm{kW}$ for the integrated system, with VCRC durations of 65 and 110 minutes respectively. The higher input power consumption of the split system comparatively facilitated its completion of the VCRC.

The power factor of both systems in all three time scenarios was an excellent 0.98. The averages for the relative humidity, ambient temperature and the in-line cold water temperature were negligible. The morning averages were respectively $69 \%, 22.0$ ${ }^{\circ} \mathrm{C}$ and $20.0^{\circ} \mathrm{C}$; with afternoon averages of $64.0 \%$, 
Table 3: Averages of the nine critical parameters when $100 \mathrm{~L}$ is drawn off.

\begin{tabular}{lcccccc}
\hline Parameter & \multicolumn{2}{c}{ Morning period } & \multicolumn{2}{c}{ Afternoon period } & \multicolumn{2}{c}{ Evening period } \\
& SIRAC & AIRCO & SIRAC & AIRCO & SIRAC & AIRCO \\
\hline $\mathrm{P}(\mathrm{kW})$ & 1.20 & 0.86 & 1.50 & 0.89 & 1.29 & 0.87 \\
$\mathrm{PF}$ & 0.98 & 0.98 & 0.98 & 0.98 & 0.98 & 0.98 \\
$\mathrm{RH}(\%)$ & 69.00 & 69.00 & 64.00 & 64.00 & 88.00 & 88.00 \\
$\mathrm{AT}\left({ }^{\circ} \mathrm{C}\right)$ & 22.00 & 22.00 & 23.00 & 23.00 & 17.30 & 17.30 \\
Ticw $\left({ }^{\circ} \mathrm{C}\right)$ & 18.70 & 18.70 & 24.00 & 24.00 & 18.70 & 18.70 \\
Tcomi $\left({ }^{\circ} \mathrm{C}\right)$ & 27.70 & 13.00 & 28.40 & 12.80 & 23.50 & 10.70 \\
Tcomo $\left({ }^{\circ} \mathrm{C}\right)$ & 73.50 & 52.60 & 76.40 & 52.90 & 71.70 & 49.70 \\
Tconi $\left({ }^{\circ} \mathrm{C}\right)$ & 71.50 & 51.50 & 75.20 & 51.40 & 70.50 & 48.70 \\
Tcono $\left({ }^{\circ} \mathrm{C}\right)$ & 37.20 & 46.70 & 37.80 & 47.50 & 36.50 & 45.90 \\
\hline
\end{tabular}

$\mathrm{P}=$ average power, $\mathrm{PF}=$ power factor, $\mathrm{RH}=$ average relative humidity, $\mathrm{AT}=$ average ambient temperature, Ticw $=$ inline cold water temperature, Tcomi = average refrigerant temperature at comprossor inlet, Tcomo $=$ average refrigerant temperature at comprossor inlet, Tconi $=$ average refrigerant temperature at condenser inlet, Tcono $=$ average refrigerant temperature at condenser inlet.

$23.0^{\circ} \mathrm{C}$ and $24.0^{\circ} \mathrm{C}$; and evening averages of $88 \%$, $17.3^{\circ} \mathrm{C}$ and $18.7^{\circ} \mathrm{C}$.

Table 3 shows the averages of the refrigerant temperature at the inlet and outlet of the compressors in the two systems in the three scenarios when $100 \mathrm{~L}$ was drawn off. In the morning, although the average temperature of the refrigerant at the inlet of the compressor in the integrated system, at $13.0^{\circ} \mathrm{C}$, was lower than that of the split system, at $27.7^{\circ} \mathrm{C}$, for the split type greater thermal energy was gained by the refrigerant as it entered the suction end and exited the discharge end. The amount of the thermal energy gained was a function of the change in the temperature of the refrigerant at the inlet and outlet of the compressor and was $45.8^{\circ} \mathrm{C}$ and 39.6 ${ }^{\circ} \mathrm{C}$ for the split and integrated types respectively. Afternoon averages show that the refrigerant temperature at the inlet of the compressor in the integrated system was $12.8^{\circ} \mathrm{C}$, compared with $28.4^{\circ} \mathrm{C}$ for the split type system. There was a greater thermal energy gained by the refrigerant in the split type, with the difference in temperature of the refrigerant at the inlet and outlet of the compressor being $48.0^{\circ} \mathrm{C}$ and $40.1^{\circ} \mathrm{C}$ for the split and integrated types respectively. The evening drawing-off showed the average refrigerant temperature at the inlet of the compressor in the integrated type system at $10.7^{\circ} \mathrm{C}$, compared with $23.5^{\circ} \mathrm{C}$ for the split type system. The corresponding difference in temperature of the refrigerant at the inlet and outlet of the compressor was $48.2{ }^{\circ} \mathrm{C}$ and $39.0^{\circ} \mathrm{C}$ for the split and integrated types respectively.

Table 3 shows the averages of refrigerant temperature at the inlet and outlet of the condensers in both systems. The amount of useful thermal energy gained by the water strongly correlated with change in the refrigerant temperature between the inlet and outlet of the condenser. This difference was $29.5^{\circ} \mathrm{C}$ for the morning drawn-off (from $34.3^{\circ} \mathrm{C}$ to $4.8^{\circ} \mathrm{C}$ ) in the split and integrated systems. The difference in the afternoon was $33.5^{\circ} \mathrm{C}$ (from $37.4^{\circ} \mathrm{C}$ to $3.9^{\circ} \mathrm{C}$ ).
The evening difference was $32.0^{\circ} \mathrm{C}$ (from $34.8{ }^{\circ} \mathrm{C}$ to $2.8{ }^{\circ} \mathrm{C}$ ) between the change in refrigerant temperature at the inlet and outlet of the condensers.

Analysis, supported by theory, thus showed that the split type had a better performance than the integrated type, with a higher refrigerant temperature difference between the condenser inlet and outlet.

\subsection{Summer performance of the two systems when $150 \mathrm{~L}$ of hot water is drawn off}

The procedure described in Section 4.1 was repeated, but this time with $150 \mathrm{~L}$ of hot water drawn off. Table 4 shows the averages of the nine parameters examined.

The average power consumption of the split type system was $1.25 \mathrm{~kW}$, compared with $0.83 \mathrm{~kW}$ for the integrated type system, with VCRC durations respectively 85 and 145 minutes during the morning session. In the afternoon, average power consumption of the split and integrated systems were $1.33 \mathrm{~kW}$ and $0.86 \mathrm{~kW}$ respectively, with VCRC durations of 75 and 125 minutes. In the evening, average power consumption was $1.28 \mathrm{~kW}$ and $0.86 \mathrm{~kW}$ for the split and integrated systems respectively, with VCRC durations of 90 and 145 minutes. The higher input power consumption of the split system allowed for a shorter time taken for completing the VCRC. The power factor profiles for both systems was an excellent 0.98 in all three periods. There were no clear differences for the two systems in relative humidity, ambient temperature and the initial cold water temperature. The averages of the relative humidity, ambient temperature and inline cold water temperature for both systems were $70 \%, 22.8^{\circ} \mathrm{C}$ and $23.2^{\circ} \mathrm{C}$ in the morning period; in the afternoon they were $35.0 \%, 27.0{ }^{\circ} \mathrm{C}$ and 25.0 ${ }^{\circ} \mathrm{C}$, and in the evening they were $67 \%, 18.2^{\circ} \mathrm{C}$ and $21.2^{\circ} \mathrm{C}$

Table 4 shows that the average temperature of the refrigerant at the inlet of the compressor in the 
Table 4: Averages of the nine critical parameters when $150 \mathrm{~L}$ is drawn off.

\begin{tabular}{lcccccc}
\hline Parameter & \multicolumn{2}{c}{ Morning period } & \multicolumn{2}{c}{ Afternoon period } & \multicolumn{2}{c}{ Evening period } \\
& SIRAC & AIRCO & SIRAC & AIRCO & SIRAC & AIRCO \\
\hline $\mathrm{P}(\mathrm{kW})$ & 1.25 & 0.83 & 1.33 & 0.86 & 1.28 & 0.86 \\
$\mathrm{PF}$ & 0.98 & 0.98 & 0.98 & 0.98 & 0.98 & 0.98 \\
$\mathrm{RH}(\%)$ & 70.00 & 70.00 & 35.00 & 35.00 & 67.00 & 67.00 \\
$\mathrm{AT}\left({ }^{\circ} \mathrm{C}\right)$ & 22.80 & 22.80 & 27.00 & 27.00 & 18.20 & 18.20 \\
Ticw $\left({ }^{\circ} \mathrm{C}\right)$ & 23.20 & 23.20 & 25.00 & 25.00 & 21.20 & 21.20 \\
Tcomi $\left({ }^{\circ} \mathrm{C}\right)$ & 23.20 & 11.10 & 35.60 & 11.10 & 22.60 & 9.70 \\
Tcomo $\left({ }^{\circ} \mathrm{C}\right)$ & 71.90 & 48.60 & 83.80 & 53.00 & 71.00 & 48.30 \\
Tconi $\left({ }^{\circ} \mathrm{C}\right)$ & 70.40 & 47.50 & 82.50 & 52.00 & 70.00 & 47.50 \\
Tcono $\left({ }^{\circ} \mathrm{C}\right)$ & 33.00 & 42.70 & 39.10 & 47.00 & 33.10 & 44.20 \\
\hline
\end{tabular}

$\mathrm{P}=$ average power, $\mathrm{PF}=$ power factor, $\mathrm{RH}=$ average relative humidity, $\mathrm{AT}=$ average ambient temperature, Ticw $=$ inline cold water temperature, Tcomi = average refrigerant temperature at comprossor inlet, Tcomo $=$ average refrigerant temperature at comprossor inlet, Tconi $=$ average refrigerant temperature at condenser inlet, Tcono $=$ average refrigerant temperature at condenser inlet.

integrated system was lower than that of the split system in the morning, at $11.1{ }^{\circ} \mathrm{C}$ and $23.2{ }^{\circ} \mathrm{C}$; afternoon at $11.1{ }^{\circ} \mathrm{C}$ and $35.6{ }^{\circ} \mathrm{C}$; and evening at $9.7^{\circ} \mathrm{C}$ and $22.6^{\circ} \mathrm{C}$. The change in the temperature of the refrigerant at the inlet and outlet of the compressors was $48.7{ }^{\circ} \mathrm{C}$ and $37.5^{\circ} \mathrm{C}$ for the split and integrated systems, respectively, in the morning; the difference in the afternoon was $48.2^{\circ} \mathrm{C}$ and 41.9 ${ }^{\circ} \mathrm{C}$, and in the evening it was $48.4{ }^{\circ} \mathrm{C}$ and $38.6{ }^{\circ} \mathrm{C}$.

The amount of useful thermal energy gained by water was a function of the change in the refrigerant temperature between the inlet and outlet of the condenser. The difference in the change of the refrigerant temperature at the inlet and outlet of the condensers in the split and integrated systems in the morning was $32.6{ }^{\circ} \mathrm{C}$ (from $37.4{ }^{\circ} \mathrm{C}$ to $4.8^{\circ} \mathrm{C}$ ); in the afternoon 38.1 (from $43.1^{\circ} \mathrm{C}$ to $5.0^{\circ} \mathrm{C}$ ), and in the evening $33.6{ }^{\circ} \mathrm{C}$ (from $36.9^{\circ} \mathrm{C}$ to $3.3^{\circ} \mathrm{C}$ ).

Analysis, backed with the theoretical formulation of COP based on temperature lift, shows that the split type performed better than the integrated system.

\subsection{Summary of the two systems' performance}

Table 5 summarises the average performance of the split type and integrated type ASHP water heaters. In all scenarios, the average COP was more than 2 , in line with previous research (Levins, 1982; Bodzin, 1997; Tangwe et al., 2014). The energy consumption of the integrated system was greater than that of the split system because of the backup

Table 5: Comparative analysis of the two systems based on energies and COP.

\begin{tabular}{lcccccc}
\hline $\begin{array}{l}\text { ASHP } \\
\text { system }\end{array}$ & $\begin{array}{c}\text { Drawn-off } \\
(\mathrm{L})\end{array}$ & $\begin{array}{c}\text { Time } \\
(\mathrm{min})\end{array}$ & $\begin{array}{c}\text { Power } \\
(\mathrm{kW})\end{array}$ & $\begin{array}{c}\text { Electrical energy } \\
(\mathrm{kWh})\end{array}$ & $\begin{array}{c}\text { Thermal energy } \\
(\mathrm{kWh})\end{array}$ & COP \\
\hline Integrated & 50.0 & 69.88 & 0.85 & 0.99 & 2.19 & 2.19 \\
Split & 50.0 & 34.81 & 1.31 & 0.76 & 2.32 & 2.87 \\
Integrated & 50.0 & 60.71 & 0.85 & 0.86 & 2.32 & 2.70 \\
Split & 50.0 & 40.00 & 1.14 & 0.76 & 2.45 & 3.04 \\
Integrated & 50.0 & 70.47 & 0.86 & 1.01 & 2.45 & 2.42 \\
Split & 50.0 & 40.00 & 1.35 & 0.90 & 4.20 & 2.72 \\
\hline Integrated & 100.0 & 110.82 & 0.85 & 1.57 & 4.20 & 3.68 \\
Split & 100.0 & 67.56 & 1.19 & 1.34 & 3.92 & 2.64 \\
Integrated & 100.0 & 100.91 & 0.88 & 1.48 & 3.92 & 3.01 \\
Split & 100.0 & 60.00 & 1.30 & 1.30 & 4.23 & 2.63 \\
Integrated & 100.0 & 111.03 & 0.87 & 1.61 & 6.16 & 3.02 \\
Split & 100.0 & 65.12 & 1.29 & 1.40 & 6.16 & 3.05 \\
Integrated & 150.0 & 146.02 & 0.83 & 2.02 & 4.78 & 3.46 \\
Split & 150.0 & 85.44 & 1.25 & 1.78 & 4.78 & 2.67 \\
Integrated & 150.0 & 126.35 & 0.85 & 1.79 & 5.79 & 2.87 \\
Split & 150.0 & 74.88 & 1.33 & 1.66 & 5.79 & 2.80 \\
Integrated & 150.0 & 145.41 & 0.85 & 2.06 & & 3.19 \\
Split & 150.0 & 85.98 & 1.27 & 1.82 & &
\end{tabular}


element that switched on and in conjunction with the input electrical power delivered during the VCRC as well as the lengthy period of heating cycles. The average power consumed by the integrated system during withdrawals of 50, 100 and $150 \mathrm{~L}$ was respectively $0.85,0.87$ and $0.84 \mathrm{~kW}$, compared with $1.27,1.26$ and $1.28 \mathrm{~kW}$ for the split system. Throughout the process of hot water withdrawal, the two systems showed negligible variation in power consumption. Despite this, the split system had a higher power consumption in all the scenarios, with the average electrical energy consumption lower at $0.81,1.35$ and $1.75 \mathrm{kWh}$, compared with $0.95,1.55$ and $1.96 \mathrm{kWh}$ for the integrated system. Furthermore, the average COPs of the split type, at 2.88, 3.01 and 3.17, were consistently higher than those for the integrated system, at 2.44, 2.65 and 2.84. Finally, the duration of the VCRC that occurred in all scenarios was longer in the case of the integrated heat pump water heater, because of its lower electrical input power and COP.

\subsection{Comparative analysis of the two systems' overall performance}

Tables 6 and 7 show the average COPs, power and energy consumptions of the two types of ASHP water heaters achieved for the typical summer and winter monitoring durations. The electrical and thermal energies of both systems under specific volumes of hot water drawn off were lower in summer than in winter periods, which can be accounted for by the lower ambient temperature during winter. The initial inline cold water temperature as well as the water temperature into the inlet of the ASHP are also lower in winter. The average COPs of the two types of ASHP water heaters were better in summer than in winter. In addition, there was an increase in the COPs when large volumes of hot water were withdrawn. Lastly, the average power consumptions of both types, with the corresponding specific volumes of hot water drawn off, were lower in winter because of ambient temperature. Above all, it should be noted that both systems operated simultaneously. The average ambient temperature, relative humidity and the initial in-line cold water temperature were practically equal for the different scenarios of specific volumes of hot water drawn off.

\section{Conclusions}

A residential air-source heat pump water heater is an energy-efficient technology for sanitary hot water production irrespective of the type being employed or utilised. In this experiment, the split type heater without an electric backup had a better COP than the integrated type with an electric backup. The COP was also impacted by the input electrical energy consumption. There was a significant difference between the refrigerant temperature of the inlet and outlet of the condenser in the split system to that of the integrated system. Although the increase in the difference in refrigerant temperatures at the condenser units could account for the split system having a higher $\mathrm{COP}$, the higher temperatures of the refrigerant at the inlet and outlet of the condenser unit in the split system could lead to it having a shorter lifespan. Based on the analysis, better COP was achieved when the difference between the refrigerant temperature of the inlet and

Table 6: Summer comparison of the two systems based on average energy and COP.

\begin{tabular}{lccccc}
\hline $\begin{array}{l}\text { ASHP } \\
\text { system }\end{array}$ & $\begin{array}{c}\text { Drawn-off } \\
(\mathrm{L})\end{array}$ & $\begin{array}{c}\text { Power } \\
(\mathrm{kW})\end{array}$ & $\begin{array}{c}\text { Electrical energy } \\
(\mathrm{kWh})\end{array}$ & $\begin{array}{c}\text { Thermal energy } \\
(\mathrm{kWh})\end{array}$ & COP \\
\hline Split & 50.0 & 1.1667 & 0.8067 & 2.3200 & 2.8767 \\
Integrated & 50.0 & 0.8533 & 0.9500 & 2.3200 & 2.4367 \\
Split & 100.0 & 1.2600 & 1.3600 & 4.1167 & 3.0133 \\
Integrated & 100.0 & 0.8667 & 1.5670 & 4.1167 & 2.6500 \\
Split & 150.0 & 1.2833 & 1.7467 & 5.5767 & 3.1733 \\
Integrated & 150.0 & 0.8433 & 1.9543 & 5.5767 & 2.8400 \\
\hline ASHP=Air source heat pump, COP = coefficient of performance
\end{tabular}

Table 7: Winter comparison of the two systems based on average energy and COP.

\begin{tabular}{lccccc}
\hline $\begin{array}{l}\text { ASHP } \\
\text { system }\end{array}$ & $\begin{array}{c}\text { Drawn-off } \\
(\mathrm{L})\end{array}$ & $\begin{array}{c}\text { Power } \\
(\mathrm{kW})\end{array}$ & $\begin{array}{c}\text { Electrical energy } \\
(\mathrm{kWh})\end{array}$ & $\begin{array}{c}\text { Thermal energy } \\
(\mathrm{kWh})\end{array}$ & COP \\
\hline Split & 50.0 & 1.1407 & 1.1564 & 2.6541 & 2.499 \\
Integrated & 50.0 & 0.9128 & 1.5635 & 2.6540 & 2.093 \\
Split & 100.0 & 1.2151 & 1.5994 & 4.9141 & 2.923 \\
Integrated & 100.0 & 0.8673 & 2.1612 & 4.9141 & 2.294 \\
Split & 150.0 & 1.2314 & 1.9091 & 6.0196 & 3.155 \\
Integrated & 150.0 & 0.8370 & 2.2798 & 6.0196 & 2.403 \\
\hline
\end{tabular}

$\mathrm{ASHP}=$ Air source heat pump, COP $=$ coefficient of performance 
outlet of the condenser was large. Another conclusion is that the COP of both types of ASHP water heaters performed better in summer than winter, thanks to favourable ambient conditions.

\section{Acknowledgement}

Thanks are due to Eskom for its financial support, enabling the purchase of research equipment.

\section{References}

Aprea, C., Greco, A. and Rosato, A. 2008. Comparison of R407C A heat transfer coefficient and pressure drops during flowing boiling in a horizontal smooth tube. Energy Conversion and Management, 49(6): 1629-1636.

Bodzin, S. 1997. Air-to-water heat pumps for the home Home Energy, 14(4).

Bryson, D. 2011. Eskom key reason South Africa is a big polluter. Association Press, 24, 679-684.

De Swardt, C.A. and Meyer, J.P. 2001. A performance comparison between an air-source and a groundsource reversible heat pump. International Journal of Energy Research, 25(10): 899-910.

Huang, B.J. and Lin, F.H., 1997. A compact and fast temperature-response heat pump water heater. In ASME 1997 Turbo Asia Conference, V001T13A002 V001T13A002. American Society of Mechanical Engineers.

Levins, W.P. 1982. Estimated seasonal performance of a heat pump water heater including effects of climate and in-house location (No. ORNL/CON-81). Oak Ridge National Lab., TN (USA)

Meyer, J.P. and Tshimankinda, M. 1998. Domestic hot water consumption in South African townhouses. Energy Conversion and Management, 39(7): 679684.

Morrison, G.L., Anderson, T. and Behnia, M. 2004 Seasonal performance rating of heat pump water heaters. Solar Energy, 76(1): 147-152.

Tangwe, S., Simon, M. and Meyer, E. 2016. Design of a heat pump water heater performance monitoring system: To determine performance of a split type system. Engineering Journal of Technology and Design ,14(4):739-751.

Tangwe, S., Simon, M. and Meyer, E. 2014. Mathematical modelling and simulation application to visualize the performance of retrofit heat pump water heater under first-hour heating rating. Renewable Energy 72: 203-211.

Tangwe, S., Simon, M. and Meyer, E., 2014. Analytical evaluation of the energy losses of an air source heat pump water heater: A retrofit type. Journal of Energy and Power Engineering, 8(7): 1251-1257.

Tangwe, S., Simon, M., Meyer, E.L., Mwampheli, S. and Makaka, G., 2015. Performance optimization of an air source heat pump water heater using mathematical modelling. Journal of Energy in Southern Africa 26(1): 96-105

Van Eeden, S.J., Jacobsz, S.W., Rust, M. and Rust, E., 2016. Electricity generation as a beneficial post-closure land use option for a dormant tailings storage facility. Journal of the South African Institution of
Civil Engineering, 58(1): 53-61.

Ye, X., Xia, X. and Zhang J. 2012. Residential heat pump rebate programme. Energy efficiency measurement and verification practices, Ed. Xia, X. and Zhang, J. Media in Africa (Pty) Ltd, Unit G, Castle Walk Corporate Park. 